\title{
611 新しい障害者用スキー「パラスキー」の開発
}

\section{Development of the new ski-system named 'Para-ski' for the disabled}

\author{
○正 土 岐 仁（秋田大） \\ 小林 義隆（秋田大院） \\ 学 渡部 慎吾（秋田大院） \\ 正 田中 雅徳（ニプロ）
}

Hitoshi DOKI, Akita University, 1-1, Tegata Gakuencho, Akita 010-8502

Shingo Watanabe, Graduate School of Akita University

Yoshitaka Kobayashi, Graduate School of Akita University

Masanori TANAKA, Nipro Corp.

Key Words: Chair Ski, Sledge Type Ski-system, Rotation Mechanism, Lift-up Mechanism,

Motion Analysis

\section{1.はじめに}

近年，身体に障害を持った人達の各種スポーツへの参加 が年々高まり, 現在ではほとんどのスポーツが盛んに行わ れるようになってきた。しかしながら，スキーに代表され る冬季スポーツへの参加はまだ十分とは言えない. そのよ うな中にあって, 両下肢障害者用スキーとしてチェアスキ 一が普及し始めてきた。これは，一本のスキーにサスペン ション機構を介して椅子が取り付けられた構造をしており， スキーヤーは両腕にアウトリガーを装着しバランスを取り ながら滑るもので，上級者になると健常者と変わらないダ イナミックな滑りを実現することが可能である．しかしな がら, 脚が一本のため, バランスをとることが難しく, ス キ一経験の全く無い障害者がチェアスキーを自由に操作す るためには, かなりの努力が必要となり，レジャースポー ツとして気軽にスキーを楽しむまでにはいたっていないよ うに思われる。

著者らは, 初心者が取り組みやすく, 安全かつ簡単にパ ラレルで滑走できる新たな両下肢障害者用スキーシステム （以後パラスキーと呼ぶ）を開発することを目的とし，こ

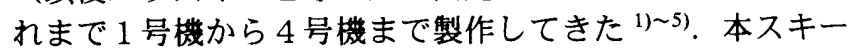
システムは, チェアスキーとは違い, 基本構造として二本 のスキー板とターンを行うための回旋動作機構を有してお り，コントロールレバーを左右に操作することで簡単にス キーターンと安全な制動を行うことができる．また，安定 性があり, 心理的にも安心感が得られるため, 両下肢障害 者のみならず重度障害者や高龄者も使用でき, 汎用性があ る.

このように本スキーシステムの滑走性能及び制動性能は 当初の目的に近いレベルにあるが，スキ一場のリフト乗車 が不可能となっていた. そこで基本性能を維持しながらも リフト乗車可能となるように，シートのリフトアップ機構 を備えたパラスキー 5 号機を開発し，実際にスキー場で利 用可能であるかを検討した結果について報告する。

\section{2.リフトアップ機構}

本研究では両下肢等の障害を持つスキー初心者を対象と しているため, 介助者の協力を前提に, 滑走性能を維持し つつスキーリフト乗車が可能となるリフトアップ機構の設 計を行う. 開発指針は以下の通りである.

（1）一般的なスキ一場のスキーリフト乗り場のシート位置 から,リフトアップ時のシート下部は雪面より $400[\mathrm{~mm}]$ とする.

（2）滑走性能に影響を与えないようにリフトアップ前にお いては重心はできるだけ低く，その位置は脚部の中心 上とする.

(3) リフトアップ機構はリンク機構を応用し, バケットシ 一トを取り付けたシートフレームを上昇させる機構と する.

(4) 図 1 の様にリフトアップするときは, 介助者によりシ 一トフレームを引き上げる. なお, 介助者の補助としてガ ススプリングを使用する事により,引き上げ作業が楽に行 えるようにする.

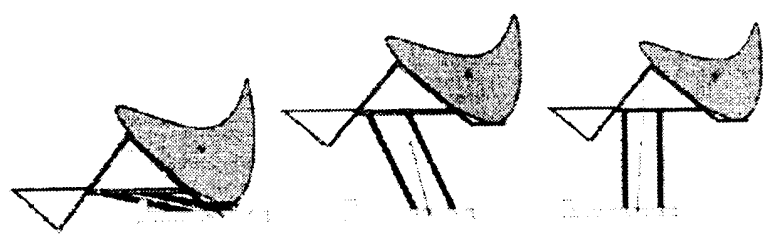

Fig. 1 Lift-up Mechanism of the Seat (Parallel Link)

平行リンク機構によるリフトアップのシミュレーション を図 1 に示す．このようにリフトアップは可能であるが, スキー場によってはスキーリフト降車時にスキ一板の先端 部分がリフト降り場に接触する可能性がある. そこでこの 点を改良するため台形リンク機構を用い, バケットシート を取り付けたシートフレームを上昇させる機構に変更した 場合のシミュレーションを図 2 に示す. 


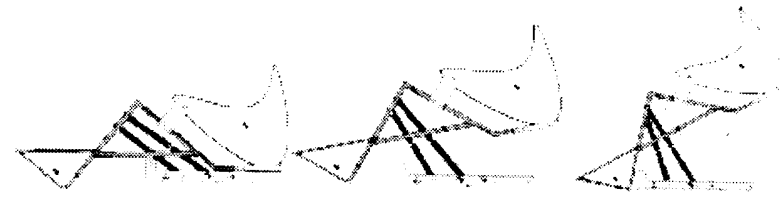

Fig. 2 Lift-up Mechanism of the Seat (Trapezoidal Link)

台形リンク機構を採用することにより，リフトアップ時 にシート後部が大きく上がり，地面に対し傾斜を持つ。こ のためスキーリフトに着座した場合，スキー板の先端部分 が相対的に上向きになり, スキーリフトからの安全な降車 が可能となる。この機構を備えたパラスキー 5 号機を図 3 に示す.

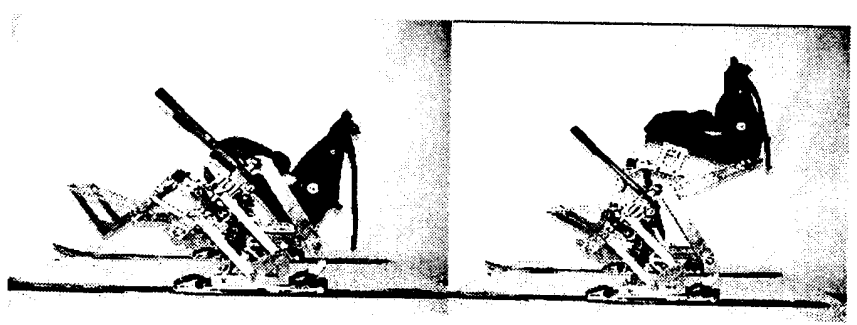

(a) Before lifting the seat

(b) After lifting the seat

Fig. 3 Side view of the Para-ski No. 5

\section{3. パラスキー 5 号機}

開発したパラスキー 5 号機は, リフトアップ機構により スキーリフトに乗車が可能である. 本スキーシステムは介 助者の協力を前提としているが, ガススプリングを用いる ことにより, リフトアップ時のシートフレームを持ち上げ る動作はきわめて軽くかつ容易である．また，ストローク ロック機構によりスキーヤー自身がその伸縮を任意の位置 で固定する事が可能である.

スキーリフト乗車は図 4 の様に安定して乗車することが 出来ることを確認した。

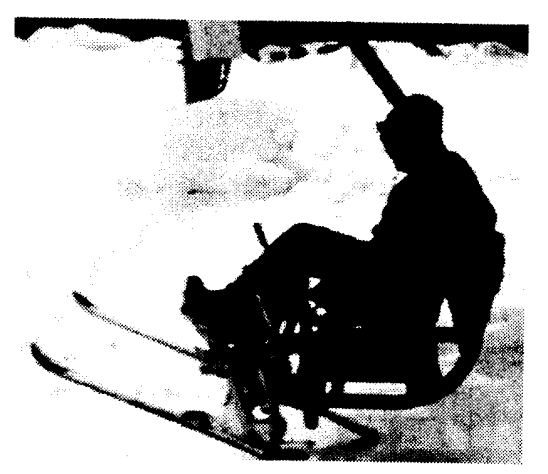

Fig. 4 How to use a ski lift

次にパラスキー 5 号機の滑走性能を評価するため, ビデ オカメラを用いた 3 次元動作解析の手法によりパラスキ一 5 号機のスキーターンの軌跡を求め, その結果からパラス キー 5 号機の滑走性能を評価した。

一例として平均斜度約 12 度の斜面において助走距離を
種々変え, パラレルによる左ターンを行ったときのスキ一 板の軌跡を図 5 に示す.なお，実験で用いたスキ一板は， 長さ $150[\mathrm{~cm}]$, サイドカットの曲率半径 $12[\mathrm{~m}]$ のカービング スキーである.いずれの結果もパラスキー 5 号機は非常に きれいなターン弧を描いており，全体に安定したターンを 実現していることが分かる.これよりパラスキー5号機は 滑走性能を維持したまま, さらにスキーリフトの乗降車が 可能となり，利便性もよいといえる.

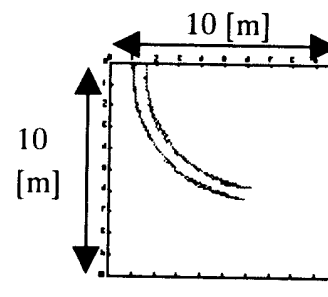

Run-up dis. $0[\mathrm{~m}]$

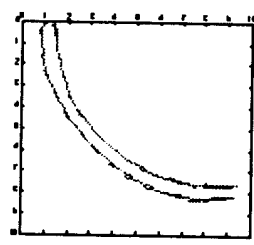

$5[\mathrm{~m}]$

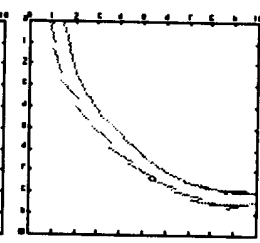

$10[\mathrm{~m}]$
Fig. 5 Paths of the ski plates in left turn by Para-ski No. 5

\section{4. おわりに}

初心者でも簡単にかつ安全にスキー滑走を行え，さらに スキーリフトへの乗車と降車が可能なパラスキー 5 号機を 製作した.リフトアップ機構のため全体として重くなった が，基本的な滑走性能及び制動性能を確保していることを 3 次元動作解析により明らかにした．また，障害者による 試乗により, 安全なリフト乗降が可能であることを確認し た。

本研究で開発したリフトアップ機構を有する両下肢障害 者用スキーにより，リアトを利用してゲレンデを上り，自 由な滑走を楽しみゲレンデを滑り降りるという一連の動作 が可能となり，本スキーシステムの使用範囲を大幅に広げ ることができた，両下肢障害者用スキーとしてリフトアッ プ機構を備えたため重量增加となったが, アルミパイプの 使用等によりさらなる軽量化は可能であると思われる.

\section{考支献}

1) 土岐仁, 平元和彦, 小貫陽一, 西村信三: 両下肢障害者 用スキーの開発(実機による滑走試験), 日本スキ一学会誌, 第 9 巻, 第 1 号, 39 頁 45 頁. (1999)

2) 土岐 仁: 障害者スキー研究の動向と展望, 日本スキ一 学会誌, 第 9 巻, 第 2 号, 91 頁 94 頁. (1999)

3) 土岐仁, 平元和彦, 田中雅徳, 寺尾專: 両下肢障害者用 スキーの動作解析（スキーロボットによるターンの解析）, 日本スキー学会誌, 第 10 巻, 第 1 号, 119 頁 126 頁. (2000) 4) 土岐仁, 平元和彦, 田中雅徳, 寺尾專 : 回旋機構による スレッジ型両下肢障害者用スキーの開発（第 1 報 実機 2 号機の性能試験), 日本スキ一学会誌, 第 10 巻, 第 1 号, 151 頁 157 頁. (2000)

5) Doki, H., Hiramoto, K., Tanaka, M. and Iwami, T.: Development of new ski-system for legs-disabled persons, The Engineering of Sports 4, Edited by S. Ujihashi and S. J. Haake, Blackwell Publishing, pp. 609-615. (2002) 